\title{
EVALUATION OF CORPORA LUTEA EFFECT ON OVARIAN MORPHOMETRY, FOLLICULAR POPULATION AND BIOCHEMICAL PROFILE IN FOLLICULAR FLUID AND BLOOD OF SLAUGHTERED COWS
}

\author{
MERVAT, S.H. ${ }^{1}$ and MARWA EL-ZEFTAWY ${ }^{2,3}$ \\ ${ }^{1}$ Theriogenology Department, Faculty of Veterinary Medicine, The New Valley University, New Valley, Egypt \\ ${ }^{2}$ Biochemistry Department, Faculty of Veterinary Medicine, The New Valley University, New Valley, Egypt. \\ ${ }^{3}$ Biological Screening and Preclinical Trial Lab, Biochemistry Department, Faculty of Science, \\ Alexandria University, Alexandria, Egypt.
}

Received: 27 December 2018; Accepted: 30 January 2019

\begin{abstract}
Cows are occupied huge economic importance worldwide. Impaired fertility in cows due to absence of corpus luteum (CL) faces huge challenge. The aim of this study was to determine the effect of CL on ovarian biometry, follicular population, hormonal and metabolic content of serum and follicular fluid (FF) of cows. Blood samples and 48ovarieswerecollected from cows slaughtered at winter season and classified according to the presence or absence of CL into two groups, ovaries with and without CL. The diameter of antral follicles was taken and classified into three subgroups, small, medium and large follicles. FF aspirated from each follicle group. 17 $\beta$ Estradiol $\left(\mathrm{E}_{2}\right)$, progesteron $\left(\mathrm{P}_{4}\right)$, glucose, total proteins, total cholesterol $(\mathrm{TC})$ and nitric oxide $(\mathrm{NO})$ were estimated. Result showed that the ovarian biometry was higher in right than left ovaries without significant difference. However, the total follicular populations and ovarian dimensions and their weights were significantly higher in ovaries with CL. The average number of small and medium follicles was also significantly increased in the ovaries with CL. However, the number of LF was higher in cows without CL compared to cows with CL. Glucose, Total cholesterol (TC), proteins, $\mathrm{E}_{2}$ and $\mathrm{P}_{4}$ concentrations were higher in serum than FF. Serum $\mathrm{E}_{2}$ concentration was higher in LF and significantly reduced in ovaries had CL than without CL. On the other hand, $\mathrm{P}_{4}$ concentration in FF was lower in LF and significantly increased in ovaries with CL. Ovaries had CL showed elevation of FF glucose level; however, TC, protein and NO concentrations were lower than ovaries without CL. Hence, we concluded that CL presence effects on both morphometric and metabolic conditions of cows' ovaries.
\end{abstract}

Key words: Corpus luteum; Ovarian follicles; Estrogen; Progesteron; Cows.

\section{INTRODUCTION}

Ovaries are primary organ of reproduction which responsible for gametogenesis and steroidogenesis during different stages of estrous cycle and pregnancy. Morphological and biometrical changes which occur in ovaries are related to number and size of developing follicles and developmental stages of the corpus luteum (CL) during estrus cycle, pregnancy, puerperium and lactation (Miranda-Moura et al., 2010).

CL is a temporary endocrine gland formed after ovulation of the ovulatory Graffian follicle and it is essential to regulate the estrous cycle and pregnancy maintenance (Tomac et al., 2011). During different

Corresponding author: Mervat, S.H.

E-mail address: mervat.vet@yahoo.com

Present address: Theriogenology Department, Faculty of Veterinary Medicine, The New Valley University, New Valley, Egypt stages of the estrous cycle and pregnancy, CL has several variations in size, structure and steroidogenic activities (Fields and Fields, 1996). CL has a hormonal secretory function such as $\mathrm{P}_{4}, \mathrm{PG}, \mathrm{E}_{2}$, relaxin, oxytocin, vasopressin and inhibin secretion (Fields, 1991). P4is the principal steroid hormone necessary for establishing of pregnancy in domestic mammals (Tomac et al., 2011). It also suppresses the secretion of the gonadotrophins which prevent behavioral estrous activity (Powell et al., 2006; Shabankareh et al., 2015).

Follicular fluid is a vascular compartment inside the mammalian ovary, separated from the perifollicular stroma by follicular wall which constitutes a bloodfollicle barrier (Abd-Ellah et al., 2010; Albomohsen et al., 2011). FF contains locally produced substances related to the follicular cells metabolic activity and steroid hormonesas $\mathrm{E}_{2}, \mathrm{P}_{4}$, and testosterone (Blaszczyk et al., 2006). These steroid hormones and metabolites are an important factor which affects oocyte maturation and early embryo development (Bender et al., 2010). 
The aim of the current study was to evaluate the effect of CL on i: ovarian morphometry and its follicular population and ii: $\mathrm{E}_{2}$ and $\mathrm{P}_{4}$, glucose, $\mathrm{TC}$, protein, and NO concentrations in both serum and FF from small, medium and large-sized follicles in cows.

\section{MATERIALS AND METHODS}

\section{Animals protocol and sample preparation}

Forty-eight adult non-pregnant cows aged (5-7 years), were obtained from Bani Adi and Moesha Abattoirs, Assiut, Egypt. They were in good health condition and without any reproductive disorders.

Blood samples were collected from jugular vein of cows before slaughtering. One of blood sample was collected in sodium fluoride and potassium oxlate tube for blood glucose estimation and other sample collected in Wisterman's tubes for other parameters determination. Blood samples centrifuged at 3000 rpm for $10 \mathrm{~min}$. The obtained plasma and serum were kept at $-20^{\circ} \mathrm{C}$ till the time of biochemical analysis.

After animal slaughtered ovaries were exised immediately and washed with ice-cold saline, wrapped in plastic sheets, placed in an icebox, and transported to the laboratory within 30 minutes after slaughtered. Ovaries associated with pregnant cows and those with any pathological lesions were not included in the study. The obtained ovaries were classified according to the presence or absence of CL. Each ovaries group was transferred into two sterile separate glass beakers.

The length (from pole to pole), width (from side to side) and thickness (from attached portion or hillus to the free surface) were measured by Vernier Caliper to the nearest $0.1 \mathrm{~mm}$. Also, all visible antral follicles on the ovarian surface in each group were counted, with classified according to their diameters (Driancourt et al., 1991) into small follicles (SF) ( $<5 \mathrm{~mm})$, medium follicles $(\mathrm{MF})(5-8 \mathrm{~mm})$ and large follicles (LF) (>8 mm) (Fig.1). The weight of each intact ovary was taken to the nearest $0.01 \mathrm{~g}$ using an electric balance (ACCULAB-V-1mg). After that, FF was aspirated from each follicle group separately using $1 \mathrm{ml}$ disposable Primo syringe to the nearest $0.01 \mathrm{ml}$. The collected FF added in Eppindorf tube, centrifuged at $3000 \mathrm{rpm}$ for $10 \mathrm{~min}$. and stored at $20^{\circ} \mathrm{C}$ till the time of biochemical analysis.
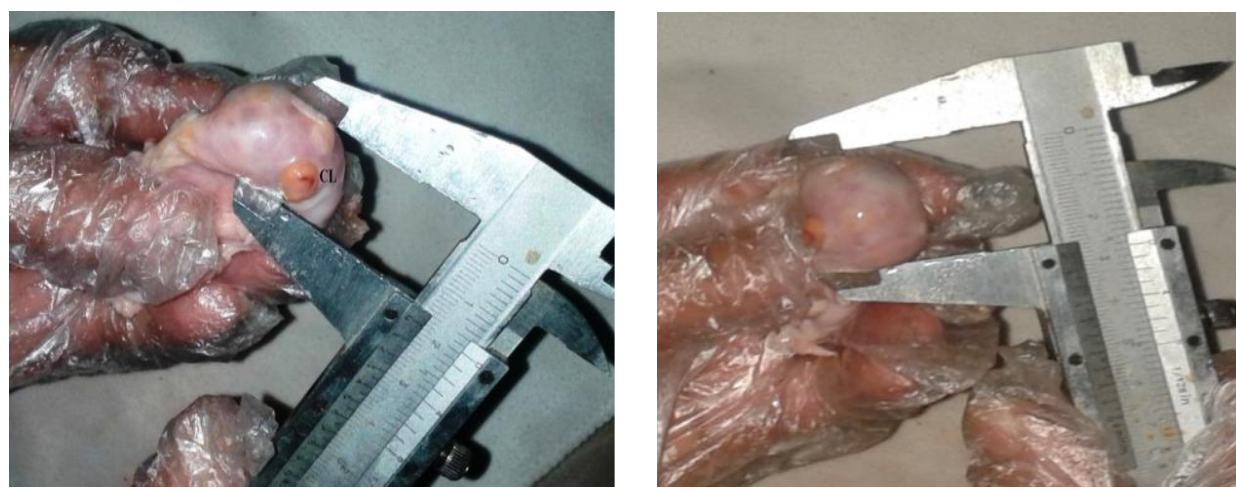

Fig. 1: Measuring ovarian morphometry by Vernier Calipers

\section{Materials}

ELISA kits of $\mathrm{P}_{4}$ and $\mathrm{E}_{2}$ were purchased from Biovision (USA). Kits of glucose, protein, TC, was obtained from Biomed (Egypt). Sulphanilamide, N(1-naphthyl) ethylenediamine, sodium nitrite, and phosphoric acid were HPLC-grade and brought from Merck (USA).

\section{Biochemical estimations}

\subsection{Estimation of glucose concentration in plasma and $\mathbf{F F}$}

Glucose concentration was estimated by commercially available glucose assay kit that is dependent on glucose oxidase-peroxidase method (Trinder, 1969).

\subsection{Estimation of Total cholesterol (TC) concentration in serum and FF}

TC was determined by cholesterol oxidase peroxidase (CHOD-PAP) test (Flegg, 1973).

\subsection{Determination of protein concentration in serum and FF}

Total protein content of all assay samples (serum and FF) was estimated spectrophotometrically using commercially available kit. These values were expressed as g/dl (Wittand Trendelenburg, 1982).

\subsection{Determination of oxidative stress marker in serum and FF}

The level of Nitric oxide (NO) was determined by using Griess reagent in both serum and FF. The reddish-purple azo-dye product was measured spectrophotometrically at $540 \mathrm{~nm}$ (Menaka et al., 2009).

\section{Sandwich ELISA}




\subsection{Determination of $P_{4}$ concentration in serum and FF}

$\mathrm{P}_{4}$ was determined by ELISA method in both serum and FF according to manufacture of instruction. This assay employs the Quantitative Sandwich Enzyme Immunoassay technique. A monoclonal antibody for $\mathrm{P}_{4}$ that has been pre-coated on to a microplate. $\mathrm{P}_{4}$ in the sample competes with a progesterone enzyme conjugate for binding sites. Unbound $\mathrm{P}_{4}$ and progesterone enzyme conjugate is washed off by wash buffer. After substrate addition, the intensity of the color is inversely proportional to the concentration of $\mathrm{P}_{4}$ in the samples. A standard curve was constructed by using standard $\mathrm{P}_{4}$ and the concentration of unknown samples was calculated from the standard curve. The intra- and inter-assay coefficients of variation $(\mathrm{CVs})$ for $\mathrm{P}_{4}$ were $<10.2 \%$.

\subsection{Determination of $E_{2}$ concentration in serum and FF}

$\mathrm{E}_{2}$ was determined by ELISA method in serum and FF according to the instruction of manufacture. The procedure depends on Sandwich Enzyme-linked Immune-sorbent assay technology. Anti- $E_{2}$ antibody was pre-coated on to 96-well plates and the horseraddish peroxidaseconjugated anti- $E_{2}$ antibody was used as detection antibodies. Formation of yellow color at the end of the reaction is an indicator of enzymatic reaction occurrence. The concentration of $E_{2}$ was determined at $450 \mathrm{~nm}$ by ELISA reader. A standard curve was created by using standard $\mathrm{E}_{2}$ and the concentrations of unknown samples were calculated from the standard curve. The intra- and inter-assay coefficients of variation (CVs) for $\mathrm{E}_{2}$ were $<4.6 \%$ and $<6.2 \%$, respectively.

\section{Statistical analysis}

Data were analyzed using software package (SAS Institute Inc. 2000). Significance of means \pm SE was detected by using Duncan's Multiple Range Test (Duncan, 1955), $\mathrm{p} \leq$ (0.05-0.001).

\section{RESULTS}

\section{Effect of CL on morphometry of ovary in cows}

Dimensions of right ovaries were non-significant higher compared to left ovaries $(\mathrm{P}<0.05)$ (Table 1$)$. However, length, width and thickness of ovaries with CL were increased by $18.8 \%, 7.7 \%$, and $10.7 \%$ respectively compared to ovaries without CL (Table 2). Macroscopic examination of cow ovaries showed that their shape were oval and highly changed and distorted with the presence of CL. Further, the ovarian activity of right ovaries was more significant than left ovaries $(\mathrm{P}<0.05)$. The ratio between $\mathrm{CL}$ to ovarian weight was $(58.48 \%$; $\mathrm{P}<0.01)$ (Figs. 2 and $3)$.

Table 1: Ovarian dimensions of right and left in cows (Mean $\pm \mathrm{SE}$ ).

\begin{tabular}{ccc}
\hline Ovarian parameters & $\begin{array}{c}\text { Left ovary } \\
(\mathbf{n}=\mathbf{4 8})\end{array}$ & $\begin{array}{c}\text { Right ovary } \\
(\mathbf{n}=\mathbf{4 8})\end{array}$ \\
\hline Length $\quad(\mathrm{cm})$ & $2.44 \pm 0.64^{\mathrm{a}}$ & $2.67 \pm 0.55^{\mathrm{a}}$ \\
Width $\quad(\mathrm{cm})$ & $1.59 \pm 0.25^{\mathrm{a}}$ & $1.58 \pm 0.26^{\mathrm{a}}$ \\
Thickness $(\mathrm{cm})$ & $2.04 \pm 0.60^{\mathrm{a}}$ & $2.05 \pm 0.43^{\mathrm{a}}$ \\
Weight $(\mathrm{g})$ & $3.80 \pm 0.79^{\mathrm{a}}$ & $4.15 \pm 1.12^{\mathrm{a}}$ \\
\hline
\end{tabular}

Values represent the mean \pm SE. Data with similar superscripts in the row for same follicles are non-significant $(\mathrm{p}<0.05)$.

Table 2: Morphometry of ovaries with and without CL in cows (Mean \pm SE).

\begin{tabular}{|c|c|c|}
\hline Ovarian parameters & $\begin{array}{c}\text { Ovaries with } \mathbf{C L} \\
(\mathbf{n}=27)\end{array}$ & $\begin{array}{c}\text { Ovaries without } \mathrm{CL} \\
(\mathrm{n}=69)\end{array}$ \\
\hline Length $\quad(\mathrm{cm})$ & $2.85 \pm 0.60^{\mathrm{a}}$ & $2.40 \pm 0.55^{b}$ \\
\hline Width $\quad(\mathrm{cm})$ & $1.67 \pm 0.24^{\mathrm{a}}$ & $1.55 \pm 0.25^{b}$ \\
\hline Thickness (cm) & $2.18 \pm 0.39^{\mathrm{a}}$ & $1.97 \pm 0.56^{\mathrm{a}}$ \\
\hline
\end{tabular}

Values represent the mean \pm SE. Data with different superscripts in the row for same follicles size are significant $(\mathrm{p}<0.05)$. 


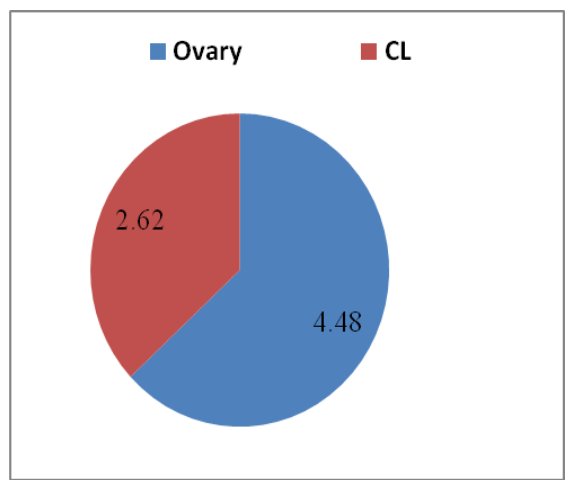

Fig. 2: Weight of ovaries and CL in examinedcows

\subsection{Effect of CL on follicular populations:}

The total follicular population of right ovary was increased by $7.5 \%$ than left ovary. Number of SF, $\mathrm{MF}$, and LF in right ovary was significantly $(\mathrm{p}<0.05)$ increased 0.2, 0.9 and 1.1-folds compared to the left ovary (Table 3). Marked significant

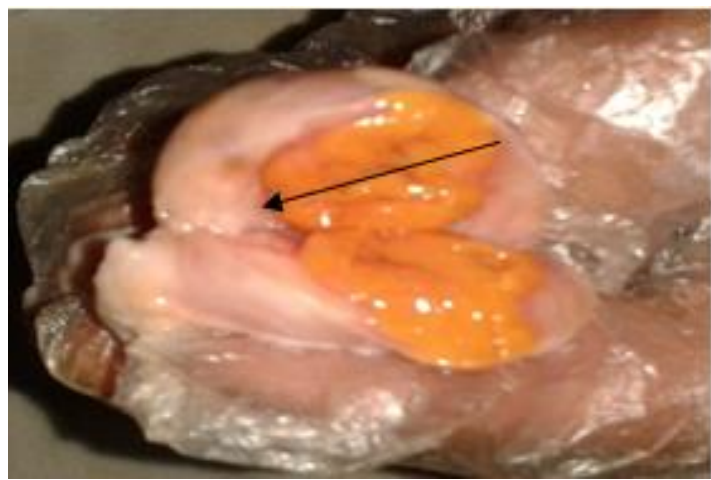

Fig. 3. Cross-section in CL of examined cows

( $<<0.01)$ increase of the number of SF and MF (by $20.3 \%$, and $33.9 \%$, respectively) of cows with CL compared to cows without CL. However, the number of LF was higher by $61 \%$ in cows without CL compared to cows with CL (Table 4).

Table 3: Follicular populations of right and left ovaries in cows (Mean \pm SE).

\begin{tabular}{|c|c|c|}
\hline Follicular populations & Right ovaries $(n=48)$ & Left ovaries $(n=48)$ \\
\hline$(<5 \mathrm{~mm})$ & $8.03 \pm 2.79^{a}$ & $6.97 \pm 2.65^{\mathrm{b}}$ \\
\hline$(5-8 \mathrm{~mm})$ & $1.68 \pm 0.85^{\mathrm{a}}$ & $0.90 \pm 0.58^{\mathrm{b}}$ \\
\hline$(>8 \mathrm{~mm})$ & $0.74 \pm 0.60^{\mathrm{a}}$ & $0.35 \pm 0.47^{\mathrm{b}}$ \\
\hline Total number of follicles & $3.74 \pm 1.38$ & $3.48 \pm 1.23$ \\
\hline
\end{tabular}

Values represent the mean \pm SE. Data with different superscripts in the row for same follicles size are significant $(\mathrm{p}<0.05)$.

Table 4: Follicular populations of ovaries with and without CL in cows (Mean $\pm \mathrm{SE}$ ).

\begin{tabular}{|c|c|c|}
\hline Follicular population & Ovaries with $\mathrm{CL}(\mathrm{n}=27)$ & Ovaries without $C L(n=69)$ \\
\hline $\mathrm{SF} \quad(<5 \mathrm{~mm})$ & $8.19 \pm 2.46^{\mathrm{a}}$ & $6.81 \pm 2.19^{b}$ \\
\hline MF $\quad(5-8 \mathrm{~mm})$ & $1.46 \pm 0.95^{\mathrm{a}}$ & $1.09 \pm 0.64^{\mathrm{a}}$ \\
\hline $\mathrm{LF} \quad(>8 \mathrm{~mm})$ & $0.66 \pm 0.56^{\mathrm{a}}$ & $0.41 \pm 0.55^{\mathrm{a}}$ \\
\hline Total & $3.35 \pm 1.32$ & $2.85 \pm 1.12$ \\
\hline
\end{tabular}

Values represent the mean \pm SE. Data with different superscripts in the row for same follicles size are significant $(\mathrm{p}<0.01)$

\subsection{Effect of $\mathrm{CL}$ on $\mathrm{P}_{4}$ and $\mathrm{E}_{2}$ concentrations in serum and FF of cows:}

Serum $\mathrm{P}_{4}$ concentration increased by $37.2 \%$ in cows with $\mathrm{CL}$ compared to cows without CL. Also, $\mathrm{P}_{4}$ level in FF obtained from SF, MF and LF of cows with CL were elevated by $13.8 \%, 8.4 \%$, and $8.6 \%$ respectively compared to cows without CL.
Moreover, $\mathrm{P}_{4}$ concentration decreased with increasing size of follicles. However, $E_{2}$ concentration increased with the increased size of the follicle. Also, $\mathrm{E}_{2}$ concentration was decreased by $15 \%, 20.7 \%, 33.1 \%$ and $43.2 \%$ in serum and FF of $\mathrm{SF}, \mathrm{MF}$ and LF of cows with CL compared to cows without CL (Table 5). 
Table 5: Hormonal concentrations $\left(\mathrm{P}_{4}\right.$ and $\left.\mathrm{E}_{2}\right)$ in serum and FF of ovaries with and without CL in cows (Mean \pm $\mathrm{SE})$.

\begin{tabular}{|c|c|c|c|c|c|}
\hline \multirow[t]{2}{*}{ Hormones } & \multirow[t]{2}{*}{ Ovaries status } & \multirow[t]{2}{*}{ Serum } & \multicolumn{3}{|c|}{ Follicular Fluid } \\
\hline & & & $\mathrm{SF}(<5 \mathrm{~mm})$ & MF (5-8 mm) & $\mathrm{LF}(>8 \mathrm{~mm})$ \\
\hline \multirow[t]{2}{*}{$P_{4}(\mathrm{ng} / \mathrm{ml})$} & With CL & $1.29 \pm 0.26^{\mathrm{a}}$ & $0.99 \pm 0.10^{\mathrm{a}}$ & $0.90 \pm 0.09^{\mathrm{a}}$ & $0.88 \pm 0.07^{\mathrm{a}}$ \\
\hline & Without CL & $0.94 \pm 0.22^{\mathrm{a}}$ & $0.87 \pm 0.09^{b}$ & $0.83 \pm 0.10^{\mathrm{b}}$ & $0.81 \pm 0.14^{b}$ \\
\hline \multirow[t]{2}{*}{$E_{2}(\mathrm{ng} / \mathrm{ml})$} & With CL & $1.75 \pm 0.36^{\mathrm{a}}$ & $0.92 \pm 0.09^{\mathrm{a}}$ & $0.93 \pm 0.05^{\mathrm{a}}$ & $0.96 \pm 0.09^{\mathrm{a}}$ \\
\hline & Without CL & $2.06 \pm 0.13^{b}$ & $1.16 \pm 0.11^{\mathrm{b}}$ & $1.39 \pm 0.17^{b}$ & $1.69 \pm 0.12^{b}$ \\
\hline
\end{tabular}

Values represent the mean $\pm \mathrm{SE}(\mathrm{n}=13)$. Data with different superscripts in the same column are significant $(\mathrm{p}<0.001)$.

\subsection{Effect of CL on glucose, TC, protein and NO} levels in plasma and/or serum and FF of cows: Plasma glucose was elevated 0.9 -fold in case of presence of CL. Moreover, in the case of CL presence glucose level in FF of SF, MF and LF of cows showed 0.4, 0.3 and 0.4 -folds increasing than in case of absence of CL (Table 6).

However, TC showed significant $(\mathrm{P}<0.001)$ decreased in serum and FF of SF, MF and LF of cows with CL compared to cows without CL by $13.6 \%, 1 \%, 9.7 \%$, and $11.7 \%$ respectively. Also reduction of total protein concentration $1.8 \%$, $16.5 \%, 17.5 \%$ and $11.2 \%$ in serum and FF of SF, MF and LF of cows with CL compared to cows without CL was noticed. NO concentration showed a marked reduction in cows has CL than those without CL in serum and FF of SF, MF and LF by $11.5 \%$, $13.9 \%, 11.6 \%$ and $12.1 \%$ respectively (Table 6 ).

Table 6: Metabolites concentrations in serum and FF of ovaries with and without CL in cows (Mean \pm SE).

\begin{tabular}{|c|c|c|c|c|c|}
\hline Metabolites & $\begin{array}{l}\text { Ovaries } \\
\text { status }\end{array}$ & $\begin{array}{c}\text { Plasma and/or } \\
\text { serum }\end{array}$ & $\begin{array}{c}\text { SF } \\
(<5 \mathrm{~mm})\end{array}$ & $\begin{array}{c}\text { MF } \\
(5-8 \mathrm{~mm})\end{array}$ & $\begin{array}{c}\text { LF } \\
(>8 \mathrm{~mm})\end{array}$ \\
\hline \multirow{2}{*}{$\begin{array}{l}\text { Glucose } \\
\text { (mg/dl) }\end{array}$} & With CL & $78.16 \pm 10.45^{\mathrm{a}}$ & $36.85 \pm 5.51^{\mathrm{a}}$ & $42.15 \pm 9.65^{\mathrm{a}}$ & $47.93 \pm 11.58^{\mathrm{a}}$ \\
\hline & Without CL & $40.39 \pm 11.39^{b}$ & $25.98 \pm 7.25^{\mathrm{b}}$ & $31.29 \pm 5.33^{\mathrm{b}}$ & $34.49 \pm 8.21^{\mathrm{b}}$ \\
\hline \multirow{2}{*}{$\begin{array}{c}\text { TC } \\
\text { (mg/dl) }\end{array}$} & With CL & $112.96 \pm 9.44^{\mathrm{a}}$ & $103.65 \pm 7.93^{\mathrm{a}}$ & $105.47 \pm 9.11^{\mathrm{a}}$ & $108.23 \pm 8.63^{\mathrm{a}}$ \\
\hline & Without CL & $130.73 \pm 5.34^{\mathrm{b}}$ & $104.72 \pm 7.48^{\mathrm{a}}$ & $116.76 \pm 9.79^{b}$ & $122.55 \pm 9.12^{b}$ \\
\hline \multirow{2}{*}{$\begin{array}{l}\text { Total protein } \\
\text { (g/dl) }\end{array}$} & With CL & $7.55 \pm 1.12^{\mathrm{a}}$ & $6.06 \pm 0.79^{\mathrm{a}}$ & $6.11 \pm 0.66^{\mathrm{a}}$ & $6.63 \pm 0.62^{\mathrm{a}}$ \\
\hline & Without CL & $7.69 \pm 0.94^{\mathrm{a}}$ & $7.26 \pm 0.65^{b}$ & $7.41 \pm 0.74^{b}$ & $7.47 \pm 0.90^{\mathrm{b}}$ \\
\hline \multirow{2}{*}{$\begin{array}{l}\text { NO } \\
(\mathrm{nm})\end{array}$} & With CL & $0.46 \pm 0.09^{\mathrm{a}}$ & $0.62 \pm 0.08^{\mathrm{a}}$ & $0.61 \pm 0.10^{\mathrm{a}}$ & $0.58 \pm 0.09^{\mathrm{a}}$ \\
\hline & Without CL & $0.52 \pm 0.14^{\mathrm{a}}$ & $0.72 \pm 0.11^{\mathrm{b}}$ & $0.69 \pm 0.11^{\mathrm{b}}$ & $0.66 \pm 0.10^{\mathrm{b}}$ \\
\hline
\end{tabular}

Values represent the mean \pm SE $(n=13)$. Data with different superscripts in the same column are significant $(\mathrm{p}<0.001)$

\section{DISCUSSION}

In recent years reproductive disorders occupied large importance; one of the main causes contribute to the reduction of fertility in cow is low $\mathrm{P}_{4}$ concentration in blood which secreted by CL. In the current study ovarian morphometry parameters were highly affected with the presence of CL which represented more than half of ovarian tissue in cows. Previous studies were done on buffaloes and showed similar results (Khandoker et al., 2011; Leal et al., 2013). Also, the present results came in accordance with previous works (S.H. Mervat, 2016; Bhajoni et al., 2018). Higher activity of right ovary more than left ovary in cows is attributed to the presence of the variations in the interior structures of the ovaries and 
presence of $\mathrm{CL}$, rather than follicles which are permanently found in the ovaries even during the early postnatal life (McEntee 1990, S.H. Mervat, 2007). It was reported that the activity of right ovary in sheep (Alsafy and EL-shahat, 2011) and cow (Rind et al., 1999) was more than left ovary.

The present data showed that the number of SF and MF was higher in the ovaries with CL than ovaries without CL. However, the number of LF was higher in the ovaries without CL as compared to ovaries with CL. These finding agreed with that reported in buffaloes (Acar et al., 2013), however disagreed with study done in cattle which showed number of MF was significantly higher in ovary without CL as compared to that with CL (Bhajoni et al., 2018).

Contreras-Solis et al. (2008) Cited that the presence of CL affects ovarian follicular dynamics in both ovaries due to secretion of $\mathrm{P}_{4}$ from $\mathrm{CL}$ which suppress $\mathrm{LH}$ pulse frequency. LH is essential for continued growth and development of LF, subsequently inhibits follicular growth (Bartlewski et al., 2001).

Additionally, results of the current study showed an elevation of $E_{2}$ in both serum and $F F$ of the cow without CL, these results were similar with obtained by Kor and Moradi (2013) Who found that elevation of $E_{2}$ in $F F$ of the cow without $C L$ was due to secretion of follicular androgen by granulosa cells which results in elevation of $\mathrm{E}_{2}$ production and these findings were similar to previous studies (Kor et al., 2013; El-Moghazy et al., 2017).

TC and total protein concentration was elevated in serum more than FF and also increased with increasing size of follicles; these finding agreed with (Kor et al., 2013, Kumar et al., 2015). Moreover, TC and total protein in FF was reduced in cows with CL compared to cows without CL as a result of low $E_{2}$ level. These results were similar in buffaloes (AbdEllah et al., 2010) and sheep (Asgharimoghadam et al., 2015), due to a high concentration of serum $\mathrm{E}_{2}$ which affect the pituitary-thyroid-adrenal axis, so serum TC was increased (Fillios and Mann, 1956). Further, $\mathrm{E}_{2}$ has a direct stimulatory effect on the liver which is the main source of all plasma proteins so reduction of $E_{2}$ directly effects on total protein concentration in both serum and FF (Ishwar and Pandey, 1994).

On the other hand, $\mathrm{P}_{4}$ concentration of both serum and FF was higher in ovaries with CL compared to ovaries without $\mathrm{CL}$ which attributed to secretion of $\mathrm{P}_{4}$ in high concentration from both granulosa and theca cells of CL (Hunter et al., 2004). The current results were agreed with previous studies (Nasroallah., 2014).

Study of glucose concentration in both plasma and FF had highly significant importance. It is known that glucose is the main source of energy for all animal body and increasing the level of glucose lead to multiple metabolic disorders. The present data showed an elevation of glucose in plasma than FF, also, glucose concentration was increased with increasing the follicle size due to reduce the rate of glucose metabolism in larger follicles as compared with smaller ones, resulting in lower consumption of glucose from fluid of large follicles (Leroy et al., 2004). Moreover, with follicular growth, increased volume of $\mathrm{FF}$ and subsequently, increased permeability of the blood follicle barrier causing higher glucose levels in large follicles (Gosden et al., 1988)

Also, glucose level of plasma and FF of cows with CL were higher compared to cows without $\mathrm{CL}$, due to secretion of $\mathrm{P}_{4}$ from $\mathrm{CL}$ which cause the change in body composition and higher levels of glucose (Moonmanee and Yammuen-arta2015). Current findings came in accordance with (Kumar et al., 2015)

Finally to evaluate the effect of CL presence on oxidative stress markers, NO determination was chosen in current study. NO is highly reactive inorganic free radical produced by many cells in the animals. Reduction of NO in both serum and FF was influenced and correlated with both $\mathrm{E}_{2}$ and $\mathrm{P}_{4}$ concentrations (Sagar et al., 2012). Out of the present study, NO concentration was decreased in cows with $\mathrm{CL}$ than those without CL. $\mathrm{E}_{2}$ induces the generation of NO in ovaries and elevation of NO levels during the follicular phase of the cycle, which essentials for follicular development, steroidogenesis, ovulation, and luteolysis, therefore $\mathrm{E}_{2}$ reduction affects NO production (Bulbul et al. 2008). On the other hand increase, $\mathrm{P}_{4}$ production by $\mathrm{CL}$ has an inhibitory effect of NO production (Sharma et al., 2016). Current results were in agreement with (Faes et al., 2007).

\section{CONCLUSION}

From this study, we concluded that corpus luteum has a great effect on ovarian morphometry and its follicular populations of different size follicles. Follicular fluid content was highly affected with the presence of corpus luteum during the different growth stage of the follicle and these contents were highly related with hormones and metabolites which affecting oocyte quality. This study can be helpful in follicular dynamics, the collection of superior oocyte quality and in vitro embryo production.

\section{ACKNOWLEDGMENTS}

This work is financially supported by Biological Screening and Preclinical Trial Lab, Biochemistry Department, Faculty of Science, Alexandria University, Alexandria, Egypt. 


\section{REFERENCES}

Abd-Ellah, M.R.; Hussein, H.A. and Derar, D.R. (2010): Ovarian follicular fluid constituents in relation to stage of estrus cycle and size of the follicle in buffalo. Vet. World.; 3: 263-267.

Acar, D.B.; Birdane, M.K.; Dogan, N. and Gurler, H. (2013): Effect of the stage of the estrous cycle on follicular population, oocyte yield and quality, and biochemical composition of serum and follicular fluid in Anatolian water buffalo. Anim. Reprod. Sci.; 137: 8-14.

Albomohsen, H.; Mamouei, M.; Tabatabaei, S. and Fayazi, J. (2011): Metabolite composition variations of follicular fluid and blood serum in Iranian dromedary camels during the peak breeding season. J. Anim. Vet. Adv.; 10: 327-331.

Alsafy, M.A.M. and El-Shahat, K.H. (2011): Morphological evaluation of ovary in relation to recovery, quality of oocytes and steroid production in sheep. J. App. Biol. Sci.; 5: 27-31.

Asgharimoghadam, M.; Hasanpoor, K.; Karamzadeh, A. and Yoosefian, I. (2015): Biochemical composition of blood plasma and follicular fluid in relation to follicular size in sheep. Indian $\mathrm{J}$. Nat. Sci.; 5: 4028-4033.

Bartlewski, P.M.; Beard, A.P. and Rawlings, N.C. (2001): Ultrasonographic study of the effects of the corpus luteum on antral follicular development in unilaterally ovulating western white-faced ewes. Anim. Reprod. Sci.; 65: 231244.

Bender, K.; Walsh, S.; Evans, A.C.O.; Fair, T. and Brennan, L. (2010): Metabolites concentrations in follicular fluid may explain differences in fertility between heifers and lactating cows. Reproduction.; 139: 1047-1055.

Bhajoni, M., Bhuyan, D.; Biswas, R.K. and Dutta, D.J. (2018): Morphometric study of ovary and rate of recovery of oocyte from medium size follicle by aspiration technique in cattle. Int. J. Chem. Studies.; 6: 499-503.

Blaszczyk, B.; Stankiewicz, T.; Udala, J.; Gaczarzewicz, D.; Lasota, B.; Blaszczyk, P.; Szymanska, A. and Szymansk-Pasternak, J. (2006): Free thyroid hormones and cholesterol in follicular fluid of bovine ovaries. Bull. Vet. Inst. Pulawy.; 50: 189-193.

Bulbul, A.; Celik, H.A.; Sireli, M.; Avci, G. and Civelek, T. (2008): Blood nitric oxide and ovarian steroids levels during the cycle stages in Brown Swiss cows. Ankara. Üniv. Vet. Fak. Derg.; 55: 155-159.

Contreras-Solis, I.; Diaz, T.; Lopez, G.; Caigua, A.; Lopez-Sebastian, A. and Gonzalez-Bulnes, A. (2008): Systemic and intraovarian effects of corpus luteum on follicular dynamics during estrous cycle in hair breed sheep. Anim Reprod Sci.; 104: 47-55.
Driancourt, M.A.; Thatcher, W.W.; Terqui, M. and Andrieu, D. (1991): Dynamics of ovarian follicular development in cattle during the estrous cycle, early pregnancy and in response to PMSG. Domestic Animal Endocrinology. Vol 8, Issue 2; 209-221.

Duncan, D.B. (1955): Multiple range and multiple F test. Biometrics.; 11:1-42.

El-Moghazy, M.M.; El-Ratel, I.T. and El-Buaa, R.F. (2017): Effect of ovarian status and follicular size on grade and maturation in vitro of bovine oocytes in relation with follicular fluid composition. J.Animal and Poultry Prod.; Mansoura Univ.; 8: 83-89.

Faes, R.F.; Caldas-Bussiere, M.C.; Rosa-e-Silva, A.A.M.; Antunes-Rodrigues, J. and Barbosa, J.C (2007): Relationship among nitric oxide, progesterone and estradiol-17 $\beta$ concentrations in follicular fluid during follicular development in cattle. Anim. Reprod.; 4: 31-37.

Fields, M.J. and Fields, P.A. (1996): Morphological characteristics of the bovine corpus luteum during the estrous cycle and pregnancy. Theriogenology.; 45: 1295-1325.

Fields, P.A. (1991): Relaxin and other luteal secretory peptides: cell localization and function in the ovary. In: Familiari, G., Makabe, S., Motta, pM. (eds.): Ultrastructure of the Ovary. Electron Microscopy in Biology and Medicine (Current Topics in Ultrastructural Research). vol 9, Springer, Boston, MA, 177-198.

Fillios, L.C. and Mann, G.V. (1956): The importance of sex in the variability of the cholesteremic response of rabbits led cholesterol. Circ. Res.; 4: 406-412.

Flegg, H.M. (1973): An investigation of the determination of serum cholesterol by an enzymatic method. Ann. Clin. Biochem.; 10:7984.

Gosden, R.G.; Hunter, R.H.F.; Telfer, E.; Terrance, C. and Brown, N. (1988): Physiological factors underlying the formation of ovarian follicular fluid. Journalof Reproduction and Fertility, 82: 813: 825.

Hunter, M.G.; Robinson, R.S.; Mann, G.E. and Webb, $R$. (2004): Endocrine and paracrine control of follicular development and ovulation rate in farm species. Anim. Reprod. Sci.; 82-83: 461477.

Ishwar, A.K. and Pandey, J.N. (1994): Blood metabolite changes in Black Bengal goats following estrus synchronization and superovulation. Small.Rumin. Res.; 13 251-256.

Khandoker, M.; Jahan, N.; Asad, L.; Hoque, S.A.M.; Ahmed, S. and Faruque, M. (2011): Qualitative and quantitative analysis of buffalo ovaries, follicles and oocytes in view of in vitro production of embryos. Bang. J. Anim. Sci.; 409,1-2:23-27.

Kor, N.M. and Moradi, K. (2013): A Review of biochemical metabolites concentration and 
hormonal composition of ovarian follicular fluid in domestic animals. Annu. Rev. Res. Biol.; 3: 246-255.

Kor, N.M.; Khanghah, K.M. and Veisi, A. (2013): Follicular fluid concentrations of biochemical metabolites and trace minerals in relation to ovarian follicle size in dairy cows. Annu. Rev. Res. Biol.; 3: 397-404.

Kumar, T.S.; Farman, M.; Nandi, S.; GirishKumar, V. and Gupta, P.S.P. (2015): Biochemical constituents of ovarian follicular fluid in ruminants and their significance in follicle and oocyte development. J. Vet. Sci. Med. Diagn.; 4: 3 .

Leal, L.S.; Moya-Araújo, C.F.; Oba, E. and Prestes, N.C. (2013): Morphometric characterization of bubaline and bovine ovaries at different phases of reproductive activity. ENCICLOPÉDIA BIOSFERA, Centro Científico ConhecerGoiânia.; 9, 1930-1939.

Leroy, J.L.; Vanholder, T.; Delanghe, J.R.; Opsomer, G.; Van Soom, A.; Bols, P.E.J.; and De Kruif, A. (2004): Metabolite and ionic composition of follicular fluid from different-sized follicles and their relationship to serum concentrations in dairy cows. Anim. Reprod. Sci.; 80: 201-211.

McEntee, K. (1990): Reproductive pathology of Domestic Mammals. Ch 3: The ovary, Academic Press, Inc. NY, Tokyo, 31-51.

Menaka, K.B.; Ramesh, A.; Thomas, B. and Kumari, N.S. (2009): Estimation of nitric oxide as antiinflammatory marker in periodontitis. J. Indian. Soc. Periodontol.; 13: 75-78.

Mervat, S.H. (2007): Some biochemical studies on follicular fluid contents of slaughtered buffaloes as related to various reproductive conditions. Master of Veterinary Science (Veterinary Theriogenology) of the Faculty of Veterinary Medicine, Assiut University.

Mervat, S.H. (2016): Biometrical and ultrasonographic studies on the reproductive genitalia of slaughtered and alive Egyptian doe. Ph.D of Veterinary Science (Veterinary Theriogenology) of the Faculty of Veterinary Medicine, Assiut University.

Miranda-Moura, M.T.M.; Fonseca, V.U.; Silva, N.B.; Freitas, M.L.; Almeida, O.B.; Rocha, H.A.O.; Papa, P.C.; Moura, C.E.B. (2010): Morphological features and vascularization study of caprine cyclic corpus luteum. Pesq. Vet. Bras.; 30: 351-357.
Moonmanee, T. and Yammuen-arta, S. (2015): Relationships among feed intake, blood metabolites, follicle size and progesterone concentration in ewes exhibiting or not exhibiting estrus after estrous synchronization in the tropics. Agriculture and Agricultural Science Procedia.; 5: 151-158.

Nasroallah, M.K. (2014): The effect of corpus luteum on hormonal composition of follicular fluid from different sized follicles and their relationship to serum concentrations in dairy cows. Asian. Pac. J. Trop. Med.; 7: 282-288.

Powell, M.L.; Kavanaugh, S. and Sower, S.A. (2006): Identification of a functional corpus luteum in the Atlantic hagfish, Myxineglutinosa. Gen. Comp. Endocrinol.; 148: 95-101.

Rind, R.; Brohi, M.A. and Bhatti, W.M. (1999): Studies on biometry of the ovary during pregnancy in buffaloes. PASF/PVMA Agro-Livestock Conf. Lahore, Pakistan.; 72-74.

Sagar, P.; Prasad, J.K.; Prasad, S.; Gupta, H.P. and Das, A. (2012): Effects of L-arginine methyl ester (L-NAME) on hormonal profile and estrus cycle length in buffaloes (Bubalusbubalis). Tropic. Anim. Health Prod.; 44: 1697-1700.

SAS Institute Inc. (2000): SAS/STAT User's Guide. Version 8: Software Manual. Cary, NC: SAS Insitute Inc.

Shabankareh, H.K.; Shahsavari, M.H.; Hajarian, H. and Moghaddam, G. (2015): In vitro developmental competence of bovine oocytes: Effect of corpus luteum and follicle size. Iran J. Reprod. Med.; 13: 615-622.

Sharma, S.; Nigam, R.; Pandey, V. and Ghuman, S.S. (2016): Plasma levels of nitric oxide and nitric oxide synthase vis à vis ovarian steroid hormones at and around estrus in cycling cowsa short communication. Veterinarski Arhiv.; 86: 867-872.

Tomac, J.; Cekinovi, D. and Arapovic, J. (2011): Biology of the corpus luteum. Periodicum Biologorum.; 113: 73-49.

Trinder, $P$. (1969): Determination of glucose in blood using glucose oxidase with on alternative oxygen receptor. Ann. Clin. Biochem.; 6: 24-27.

Witt, I. and Trendelenburg, C. (1982): Gemeinsamestudiezurerstellung von richtwertrn fur klinischchemischekenngrobenimkindesalter. J. Clin. Chem. Clin. Biochem.; 20: 235-242. 


\section{تقييم تأثير وجود الجسم الأصفر علي المقاييس الحيوية للمبيض وتعداد الجريبات والمحتوي البيوكيميائي في الجيائي السيرم والسائل الجريبي في الأبقار المذبوحة}

\section{مرفت سيل حسن ، مروه الزفتاوي}

Email: mervat.vet@yahoo.com Assiut University web-site: www.aun.edu.eg

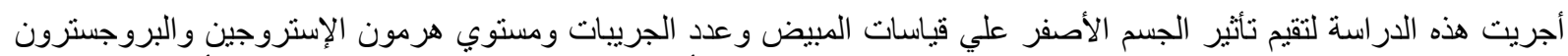

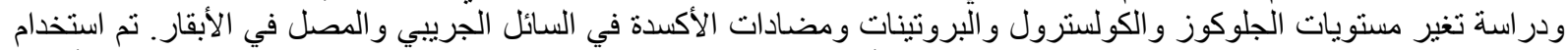

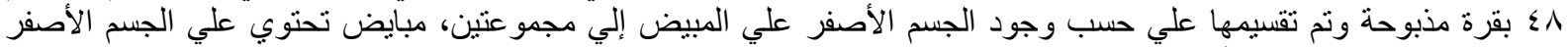

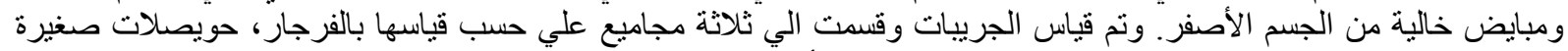

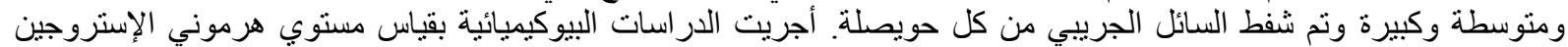

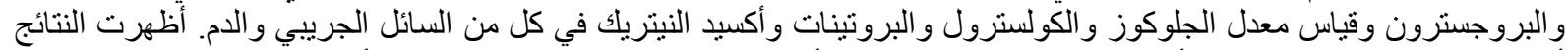

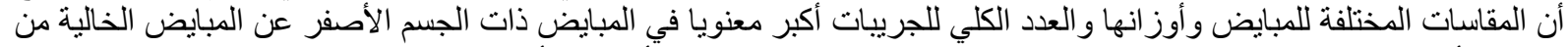

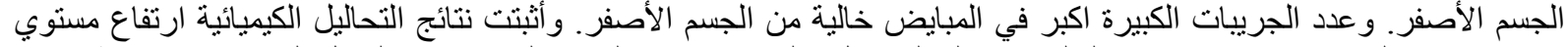

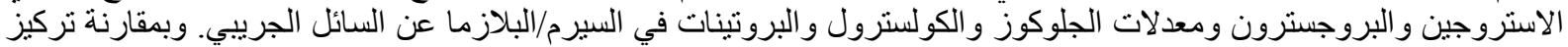

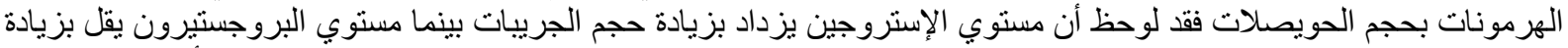

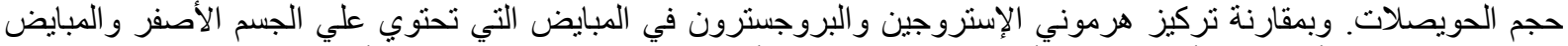

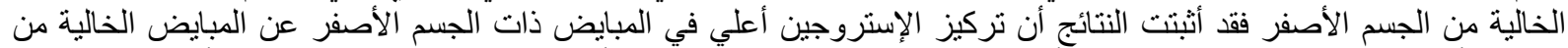

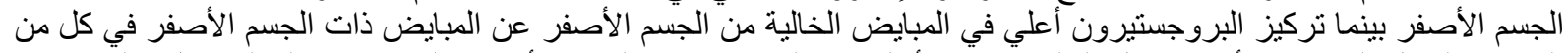

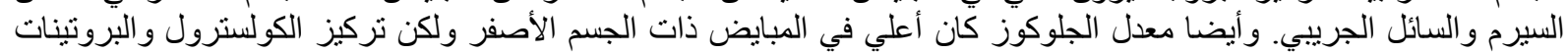
وأكسيد النيتريك كان أعلي في المبايض الخالية من الجسم الآصفر. 